\title{
Secondary bronchiolitis obliterans organizing pneumonia during treatment of chronic hepatitis C: role of pegylated interferon alfa-2a
}

\author{
Ronaldo Soares Martins ${ }^{[1],[2]}$, Juliano Antunes Machado ${ }^{[1],[2]}$ and Rosângela Teixeira ${ }^{[2],[3]}$
}

[1]. Serviço de Gastroenterologia, Hospital Felício Rocho, Belo Horizonte, MG. [2]. Instituto Alfa de Gastroenterologia, Hospital das Clínicas, Universidade Federal de Minas Gerais, Belo Horizonte, MG. [3]. Departamento de Clínica Médica, Faculdade de Medicina, Universidade Federal de Minas Gerais, Belo Horizonte, MG.

\begin{abstract}
The treatment of chronic hepatitis $\mathrm{C}$ has frequent side effects such as cytopenias and neuropsychiatric symptoms. However, pulmonary toxicity associated with interferon is rarely described. This paper describes the clinical case of a 67-year-old female patient with chronic hepatitis $\mathrm{C}$ who presented an acute onset of dry cough, dyspnoea, and fever 36 weeks after the use of pegylated interferon alfa-2a and ribavirin. The lung biopsy confirmed the diagnosis of a bronchiolitis obliterans organizing pneumonia (BOOP). Corticotherapy was initiated, with clinical and radiological improvement. This paper aims to advise physicians to this occasional, though severe, adverse event related to hepatitis $\mathrm{C}$ virus (HCV) treatment.
\end{abstract}

Keywords: Pegylated interferon alfa-2a. Bronchiolitis obliterans organizing pneumonia. Hepatitis C.

\section{INTRODUCTION}

The current therapy of chronic hepatitis $C$ is pegylated interferon (PEG-IFN) alfa-2a or $-2 \mathrm{~b}$ and ribavirin (RBV) ${ }^{1}$. The most common side effects of interferons are cytopenias and depression. Severe pulmonary toxicity of interferons has been rarely described. Due to the increase in the use of this medication in the treatment of chronic hepatitis $\mathrm{C}$, this paper aims at alerting physicians to the possibility of this occasional, though severe, adverse event during the treatment of chronic hepatitis $\mathrm{C}$.

\section{CASE REPORT}

An asymptomatic 67-year-old white woman with chronic hepatitis $\mathrm{C}$ (genotype $1 \mathrm{~b}$, liver biopsy Metavir A1F3) was referred to a treatment with PEG-IFN alfa-2a and RBV. She was not under any medication and denied tobacco addiction or alcohol abuse. Pre-treatment evaluation did not reveal any significant comorbidity. Hepatitis $C$ virus (HCV) treatment with PEG-IFN alfa-2a $(180 \mathrm{mcg} /$ week/SC) and RBV $(1,250 \mathrm{mg} / \mathrm{kg} /$ day, PO) was introduced. The initial tolerance was satisfactory, with only mild side effects of anemia $(\mathrm{Hb}=9.9 \mathrm{~g} / \mathrm{dL})$ and neutropenia (white blood count $=3,100 / \mathrm{mm}^{3}$ ).

On the $36^{\text {th }}$ week of treatment, the patient was referred to the hospital with a 5-day history of cough, malaise, and mild fever. Her physical exam revealed bilateral basal coarse crackles. No significant abnormality was noted in the complete blood count. The chest radiograph showed heterogeneous opacification bibasilar and paracardiac (Figure 1). HCV treatment was interrupted, and oral levofloxacin $(500 \mathrm{mg} /$ day) was started. As the symptoms gradually worsened despite the use of levofloxacin, it was empirically replaced by intravenous ceftriaxone $(2 \mathrm{~g} / 24 \mathrm{~h}$ ) and oral azythromycin ( $500 \mathrm{mg} /$ day),

Address to: Dr. Ronaldo Soares Martins. Serviço de Gastroenterologia/HFR. Av. do Contorno 9530, 30110-934 Belo Horizonte, MG, Brasil.

Phone: 5531 3514-7190; 5531 3514-7499

e-mail: ronaldom1@ig.com.br

Received in 05/04/2011

Accepted in 12/01/2012 and additional exams were performed. The computed tomography (CT) scan revealed bilateral pulmonary involvement, with groundglass pattern consolidations. The bronchoalveolar lavage disclosed a purulent discharge. Tests done for Pneumocystis carinii, eosinophils, human immunodeficiency virus (HIV), cytomegalovirus (CMV), Mycobacterium tuberculosis, Mycobacterium pneumoniae, Legionella pneumophila, and fungus revealed negative results. The transthoracic pulmonary biopsy revealed interstitial infiltrate of mononuclear cells, presence of plugs formed by loose fibrous tissue filling alveoli (Masson bodies), and pulmonary fibrosis, which are strongly suggestive of bronchiolitis obliterans organizing pneumonia (BOOP) (Figure 2). Oral prednisone $(1 \mathrm{mg} / \mathrm{kg})$ was promptly administered, with rapid clinical improvement. She was discharged completely recovered after 22 days of admission, with tapering dose of prednisone to complete, which was withdrawn after six months.

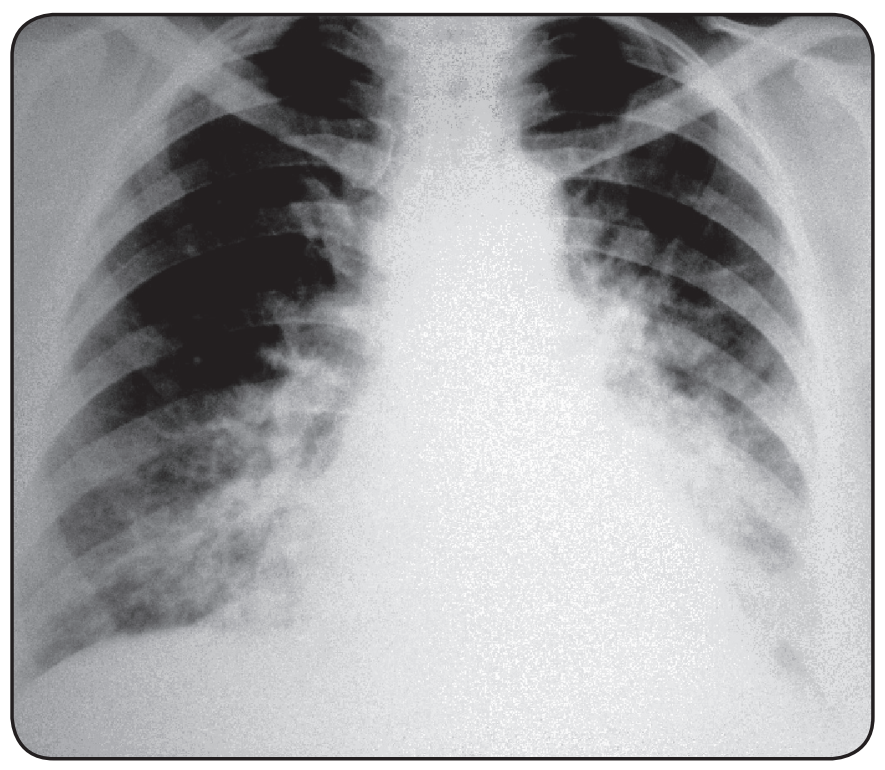

FIGURE 1 - Chest radiograph showing bibasilar and paracardiac heterogeneous opacifications. 


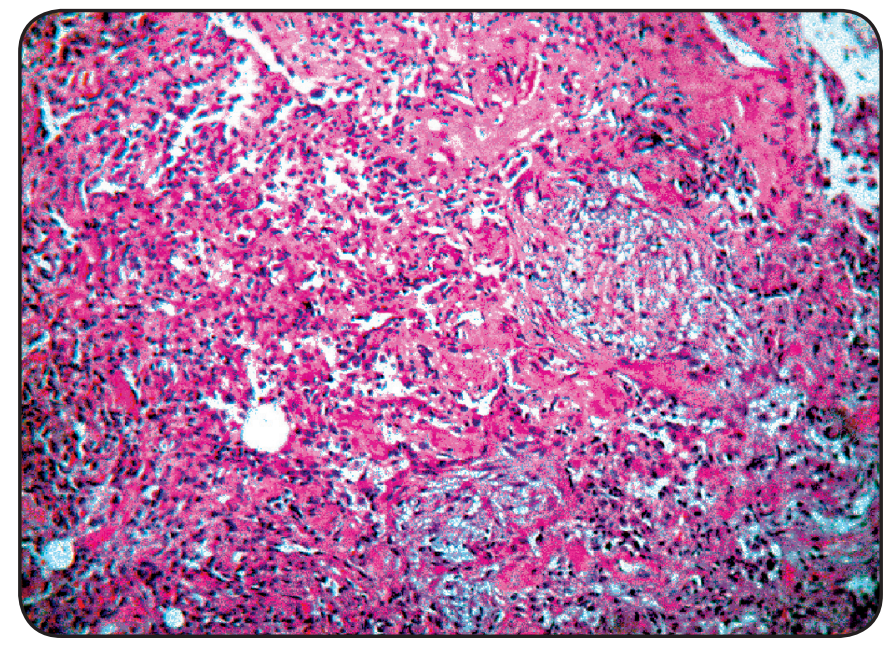

FIGURE 2 - Lung biopsy with fibrosis and interstitial infiltrate of mononuclear cells and alveoli filled by plugs of loose fibrous tissue (Masson bodies) (H\&E, x100).

\section{DISCUSSION}

BOOP is a cryptogenic or secondary nonspecific response to lung injury with high morbidity. Rare, but severe cases of organizing pneumonia (OP) or BOOP during treatment of chronic hepatitis $C$ have been reported since $1994^{1-3}$.

The occurrence of BOOP secondary to PEG-IFN alfa-2a is strongly suggested here, given the nonexistence of other factors to justify its occurrence. The nonspecific symptoms delayed the rapid diagnosis. However, the disappointing response to quinolones alerted to BOOP. In addition, the pulmonary biopsy findings, as well as the notable response to prednisone, confirmed the diagnosis.

This is the first description of BOOP related to PEG-IFN alfa-2a. It has been reported that interferons can deregulate the synthesis of the endothelial growth factor and the matrix metalloproteinase $\mathrm{e}^{4}$, thus acting as a predisposing factor to the development of BOOP. Moreover, the immunological and pharmacokinetic properties of PEG-IFN alfa-2a, with the longest half-life, might act in conjunction to trigger the pathophysiologic mechanism of $\mathrm{BOOP}^{5-6}$. Although the co-administration of RBV does not affect the pharmacokinetics of PEG-IFNs, these drugs altogether have enhanced toxicity ${ }^{5}$. Hence, it is plausible to suppose that combined drugs might have superior pulmonary toxicity. However, further studies are needed to confirm it. The fact that reports of pneumonia or BOOP associated with ribavirin monotherapy have not been published so far enhances the likelihood of BOOP induced by pegylated interferon in the case described in this report.

Regardless of the additional efficacy and safety of PEG-IFN, which is largely used in combination with RBV to treat chronic hepatitis $C$, we reported here a case of BOOP related to PEG-IFN alfa-2a, alerting physicians to this pulmonary nonspecific side effect with potential severity, given the scarcity of publications concerning this risk during the treatment of chronic hepatitis $\mathrm{C}$.

\section{ABSTRACT IN PORTUGUESE}

\author{
Bronquiolite obliterante com pneumonia em organização \\ durante o tratamento da hepatite crônica C: \\ papel do interferon peguilado alfa-2a
}

O tratamento da hepatite $\mathrm{C}$ crônica apresenta efeitos colaterais frequentes como citopenias e sintomas neuropsiquiátricos. Contudo, a toxicidade pulmonar associada ao interferon é raramente descrita. Relatamos o caso de uma paciente com 67 anos que apresentou início agudo de tosse, dispnéia e febre após 36 semanas de uso do interferon peguilado alfa-2a e ribavirina. A biópsia pulmonar confirmou o diagnóstico de bronquiolite obliterante com pneumonia em organização, com significativa melhora clínico-radiológica após instituída a corticoterapia. Este relato de caso visa alertar os médicos para a possibilidade desse ocasional, embora grave, evento adverso associado ao tratamento da hepatite $\mathrm{C}$.

Palavras-chaves: Interferon peguilado alfa-2a. Bronquiolite obliterante com pneumonia organização. Hepatite $\mathrm{C}$.

\section{REFERENCES}

1. Ogata K, Koga T, Yagawa K. Interferon-related bronchiolitis obliterans organizing pneumonia. Chest 1994; 106:612-613.

2. Abi-Nassif S, Mark EJ, Fogel RB, Hallisey Jr RK. Pegylated interferon and ribavirininduced interstitial pneumonitis with ARDS. Chest 2003; 124:406-410.

3. Suga $\mathrm{M}$, lyonaga $\mathrm{K}, \mathrm{Okamoto} \mathrm{T}$. Characteristic elevation of matrix metalloproteinase activity in idiopathic interstitial pneumonias. Am J Respir Crit Care Med 2000; 162:1949.

4. Vila JCT, López DRP, Company VB, Simón SS, Hausmann PC, Company JB. Organizing pneumonia associated with the use of pegylated interferon alfa. Arch Bronconeumol 2008; 44:173-174.

5. Zeuzem S, Welsh C, Herrman E. Pharmacokinetics of peginterferons. Semin Liver Dis 2003; 23:28.

6. Slavenburg S, Heijdra YF, Drenth JPH. Pneumonitis as a Consequence of (Peg) Interferon-Ribavirin Combination Therapy for Hepatitis C: a Review of the Literature. Dig Dis Sci 2010; 55:579-585. 